\title{
The Efficiency of Recombined Growth Hormone Therapy in Idiopathic Short Stature
}

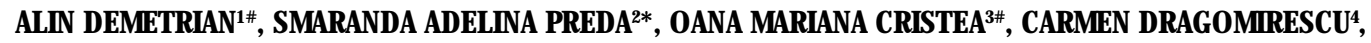 \\ IONELA MIHAELA VLADU 5 \\ 'University of Medicine and Pharmacy of Craiova, Department of Thoracic Surgery, County Hospital Craiova, 2-4 Petru Rares Str. \\ 200349, Craiova, Romania \\ 2 University of Medicine and Pharmacy, Tabaci Str, 200642, Craiova, Romania \\ ${ }^{3}$ University of Medicine and Pharmacy of Craiova, Department of Microbiology, County Hospital, 2-4 Petru Rares Str., 200349, \\ Craiova, Romania \\ ${ }^{4}$ Railway Clinical Hospital of Craiova, Department of Endocrinology, Stirbei-Voda Str., 200374, Craiova, Romania \\ ${ }^{5}$ University of Medicine and Pharmacy of Craiova, Department of Metabolism and Nutrition Diseases, Filantropia Clinical \\ Hospital of Craiova, 1 Filantropiei Str., 200143, Craiova, Romania
}

\begin{abstract}
Idiopathic short stature (ISS) deficiency reflects a major public health issue. In Romania the incidence is 1/ 3000 - 6000 births, with an increased prevalence in boys. ISS is the condition where the height of a subject is more than -2.5 DS below the height of the population for the population in which it is included, below the mean height for age and sex, but without any nutritional, systemic or chromosomal abnormalities. Significant for children with ISS is that weight is normal at birth and growth hormone levels are normal. This study shows the evolution of the height to normal values specific to the biological age, reaching the normal stature, according to auxological parameters, after growth hormone therapy
\end{abstract}

Keywords: growth hormone, idiopathic short stature

Idiopathic short stature (ISS) represents a major public health issue given the fact that, in Romania, its' incidence is $1 / 3000-6000$ births. Its' prevalence is higher in boys.

ISS is a condition in which the height of the subject is more than 2.5 SD below the heights' mean value for a given population group and below the heights' mean value for a given age and sex group, without any nutritional, endocrine or chromosomal identifiable anomalies. One characteristic in children with ISS is that the weight is normal at birth and the values of the growth hormone are normal [1].This definition of ISS includes children with a constitutional delay in growth, late onset of puberty and familial short stature. The auxological criterias are the ones that divide ISS this way. Consequently, a distinction is made between children who have a family history of short stature and the ones who have a smaller stature compared to their parent's height.

The targetheight in the standard deviations is calculated according to the following formulas [2]:

- the target height for girls in $\mathrm{cm}=$ mother's height in $\mathrm{cm}+($ father's height in $\mathrm{cm}-13) / 2$

- the target height for boys in $\mathrm{cm}=$ (mother's height in $\mathrm{cm}+13)+$ father's height in $\mathrm{cm} / 2$

Bone age also represents a criteria for classification in ISS which can indicate the probability of growth and puberty delay [3-6].

In most cases children with ISS have normal secretion and secretory dynamic of $\mathrm{GH}$ and the pharmacological $\mathrm{GH}$ provocation tests can be negative. However, the treatment with $\mathrm{GH}$ improves linear growth, even though, in children without GH treatment, the final height is considered acceptable by the family. Regarding the etiology of the slow growth rhythm in children, many subtle disturbances in the hypothalamic-hypophyseal-IGF axis are involved. [7-9]. GH secretory deficiency remains the most important pathogenic factor for the short stature in approximately $3-12 \%$ of the children with growth delay. In about $50-75 \%$ of these children, the GH decrease is idiopathic.

$\mathrm{GH}$ is secreted daily in variable quantities in the hypophysis. It totalizes about 1-5 mg and represents 4$10 \%$ from the gland's dry weight. The somatotrope hormone has a hyperglycemic and lipolytic effect, being able to mobilize the energy from the deposits, ensuring the basic energy needed for the anabolic internal processes, thus favorizing and being considered an intermediate in these processes.

The growth hormone is a polypeptide composed of 191 amino acids and contains two disulfide intramolecular bonds (between the 58-165 and 282-189 amino acids). It has a molecular weight of 22kd (B isomer 22kd variant) and is secreted by the specialized cells in the anterior hypophysis (somatotrope cells). GH shares homologue sequences with prolactin, placenta lactogen (chorionic somatotrope hormone) and a 22kd variant of GH (GH-V) which is secreted only by the placenta. The genes for these proteins are located on different chromosomes (chromosome 6 for prolactine, chromosome 17 for GH). [10-12].

\section{Experimental part}

The aim of the study

This study aims to show relevant data regarding the effects on growth hormone therapy for children with Idiopathic short stature.

\section{Material and method}

24 ISS subjects were included in our study with ages between 4 and 16 years. These patients were treated with $\mathrm{GH}$ for a period of one year. This study presents the height development to normal values for their biological age, reaching normal stature according to auxological parameters after GH therapy. 
The following criteria were used for including the ISS patients in our study:

-Normal GH values in 18 patients and values close to the lower limit in 6 patients; after the insulin induced hypoglycemia test the low basal value raised over $10 \mathrm{ng} /$ $\mathrm{mL}$;

-Normal IGF1 values in 13 patients and low values in 11 patients;

-No other height hypotrophy causes: malnutrition, genetic or systemic diseases, small weight at birth, small gestational age.

rhGH treatment was initiated in all 24 patients with a dosage of $0.2 \mathrm{mg} / \mathrm{kg} / \mathrm{week}$, being administered subcutaneously daily on a 12 months period.

In addition, tests for SSC gene polymorphism of the $\mathrm{GH}$ receptor were done in order to detect any defects of this gene.

\section{Results and discussions}

A liniar growth in the subjects' height can be noticed in the tables below with a mean value of $9.5 \mathrm{~cm}$ after one year of treatment and a Z score of the height with a mean value of -2.44 .

The BMI, chronological age and SD are presented in the table 1.

The speed of the height's improvement is shown in the table 2 .
Z score of the height also known as the relative height was calculated according to the following formula:

Z of height= real height- mean height value for the given sex and age/SD (standard deviations for the corresponding age and sex)

The values for the mean height and SD were obtained from standard anthropometric tables (Prader et.al 1998)

The mean value for the parent's height was calculated using the formula below:

MPH for boys $=($ father's height + mother's height $+13 \mathrm{~cm}) / 2$ $\mathrm{MPH}$ for girls $=($ mother's height + father's height- $13 \mathrm{~cm}) / 2$ $\mathrm{BMI}=$ weight $/$ height $^{2}\left(\mathrm{~kg} / \mathrm{m}^{2}\right)$

The analysis of the SCC polymorphism of PCR fragments in the genomic DNA has shown mutations in the $\mathrm{GH}$ receptor gene that code for the extracellular domain in 4 children (fig. 1).

These patients' profile is presented in the table 3 . The values are those before initiating the treatment

The growth rhythm and the $Z$ score of the height are shown in the table 4 with values calculated after one year of treatment.

\begin{tabular}{|c|c|c|c|c|}
\hline Parameter & No & Mean & Std Dev. & C.V. \\
\hline Chronological age & 24 & 9.76 & 3.19 & 32.70 \\
\hline $\begin{array}{l}Z \text { score of } \\
\text { height(SD) }\end{array}$ & 24 & -3.24 & $0.85^{\circ}$ & -26.35 \\
\hline $\mathrm{BM}^{-}$ & $24^{-}$ & 15.52 & 1.62 & 10.44 \\
\hline $\mathrm{MHP}(\mathrm{cm})$ & 24 & 164.88 & 10.02 & 6.07 \\
\hline
\end{tabular}

Table 1

CHARACTERISTICS OF ISS PATIENTS BEFORE TREATMENT

\begin{tabular}{|l|l|l|l|l|}
\hline Parameter & No & Mean & Std.Dev. & C.V. \\
\hline $\begin{array}{l}\text { Z score of height after } \\
\text { 1 year (SD) }\end{array}$ & $\mathbf{2 4}$ & $-\mathbf{2 . 4 4}$ & 0.96 & $-\mathbf{3 9 . 4 1}$ \\
$\begin{array}{l}\text { Growth speed under } \\
\text { treatment (cm) }\end{array}$ & $\mathbf{2 4}$ & $\mathbf{9 . 5 0}$ & $\mathbf{2 . 6 6}$ & $\mathbf{2 7 . 9 8}$ \\
\hline
\end{tabular}

Table 2

CHARACTERISTICS OF ISS PATIENTS AFTER TREATMENT
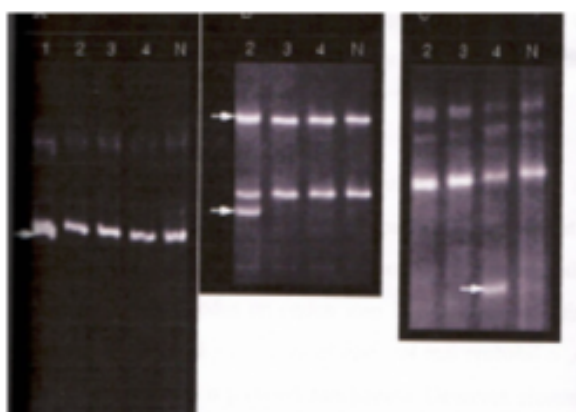

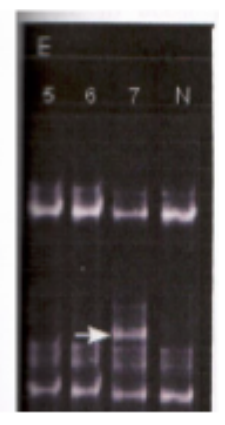

Fig. 1. SCC polymorphism analysis of PCR fragments in the genomic DNA from the 4 children who present mutations in the $\mathrm{GH}$ receptor gene. Normal subjects $(\mathrm{N})$ were included in each figure. A-7th exon in patients 1,2 , 3 and 4; the excess band in the PCR product obtained from patient 1 (arrow) indicates the presence of a mutation. B- $5^{\text {th }}$ exon in patients 2, 3 and 4 with excess bands (arrows) in the PCR products from patient 2. C, $D-4^{\text {th }}$ exon in $C$ and $6^{\text {th }}$ exon in $D$ from patients 2,3 and 4. Excess bands can be noticed in patient 4 . E- $7^{\text {th }}$ exon in patients $6=5,6$ and 7 with an excess band (arrow) from the probe that belongs to patient 7 .

\begin{tabular}{|l|l|l|l|l|l|}
\hline Patient & Sex & Chronological age & Z score of height & GH* & IGF1 \\
\hline $\mathbf{l}$ & $\mathrm{M}$ & 8 years & $-2.76 \mathrm{SD}$ & 0.45 & low \\
\hline $\mathbf{2}$ & $\mathrm{M}$ & 16 years & $-2.64 \mathrm{SD}$ & 2.49 & normal \\
\hline $\mathbf{4}$ & $\mathrm{F}$ & 6 years 11 months & $-3.28 \mathrm{SD}^{*}$ & 0.15 & normal \\
\hline $\mathbf{7}$ & $\mathrm{F}$ & 5 years 4 months & $-3.20 \mathrm{SD}^{-}$ & 2.13 & low \\
\hline
\end{tabular}

Table 3

PROFILE OF PATIENTS WITH GENETIC MUTATIONS BEFORE TREATMENT

\begin{tabular}{|l|l|l|}
\hline Pactient & Z score of height after treatment & Growth speed during treatment \\
\hline $\mathbf{1}$ & $-2.22 \mathrm{SD}$ & $8 \mathrm{~cm} /$ year \\
\hline $\mathbf{2}$ & $-2.27 \mathrm{SD}^{-}$ & $5 \mathrm{~cm} /$ year \\
\hline $\mathbf{3}$ & $-2.73 \mathrm{SD}$ & $8 \mathrm{~cm} / \mathrm{year}$ \\
\hline $\mathbf{4}$ & $-3.49 \mathrm{SD}^{-}$ & $4 \mathrm{~cm} /$ year \\
\hline
\end{tabular}

Table 4

PROFILE OF PATIENTS WITH GENETIC MUTATIONS AFTER TREATMENT 
Initially, before 1985, the hormone used for therapy was extracted from the pituitary gland from cadavers. After this period the recombined growth hormone formula was introduced [13] which is the only efficient therapy in child growth deficiency with various etiologies: idiopathic short stature, GH deficiency, Turner syndrome, Prader-Willi syndrome, chronic renal failure [13-16].

During the past few years rhGH therapy has largely extended its' use, including, nowadays, in treating ISS [17, 18].

The GH therapy's final purpose is to manage to achieve the individual's height according to his genetic potential.

One of the rhGH treatments' most important effect is the growth rhythm [13] but different metabolisms are also being influenced. Therefore, the cellular protein synthesis is accelerated and also the transfer of the aminoacids though the cellular membrane and their incorporation in the newly synthesized proteins are stimulated [19-24] In addition, it affects the formation of hydroxiproline and osteocalcin, thus stimulating the growth of the bone cartilage. This effect is better shown at the epiphyseal plate [25] through the osteoclastic and osteoblastic processes $[18,19,26]$.

GH's lipolytic action is confirmed by the decrease of the subcutaneous and visceral adiopus tissues after initiating the treatment with this hormone in patients with $\mathrm{GH}$ deficiency. Initially high values of the LDL-cholesterol and a high increase in body fat (both subcutaneous and visceral) were observed in those patients [26-32].

GH stimulates gluconeogenesis and it inhibits the glycolysis through pyruvate kinase [32].

Regarding the phospho-calcic metabolism, GH intensifies the intestinal absorption of calcium [10, 13], increases tubular reabsorption of phosphorus and stimulates the secretion of parathormon [33] The statural jump in children with GH deficiency is accomplished through the primary action of IGFI on the growth cartilage of the long bones [10]. Other effects of $\mathrm{GH}$ on the bones are already noted: remodeling phenomenon, osteoblastic hypertrophy, mineralization [26].

In our study, the treatment with genetically recombined growth hormone was administered and its' effects were evaluated after one year in all the included patients. rGH was administered through daily injections of a dosage that was calculated for each patient taking into consideration their individual weight. However, one disadvantage of a daily based treatment is that it can bring some discomfort to the patient. To aid with this problem a study was reported showing a raise in the patients' compliance to treatment by using a weekly GH administration plan [21].

The speed of the height's increase after therapy was the main indicator of the therapeutic effect.

In the review made after one year of treatment, improvements were noticed both regarding the speed of the growth butalso the mean value of the Z score of height from -3.24 SD to $-2.44 S D$.

Out of the 4 children with GHR mutations, 3 had a slight improvement of the $Z$ score of the height after treatment and in one patient the stature deficit accentuated from 3.20DS to -3.44SD. How ever, it is difficultcu assess whether the weak response to treatment in 3 out of these 4 children with genetic defect was due to the anomalies that were discovered or other factors can be an influence: low dose of rhGH or the biological age. The genetic test brings a new dimension in investigating short stature but the nature of particular mutations is not a predicting factor in $\mathrm{GH}$ therapy response. In this sense, studies have shown that mutations in the $3^{\text {rd }}$ exon were associated with a decreased response to rhGH therapy compared to a full-length isoform [25].

In order to fully assess the impact of rhGH therapy in patients with genetic modifications more extensive genetic studies are necessary [9].

\section{Conclusions}

GH substitution therapy with the purpose of obtaining a height as close to normal as possible managed to prove that, for the children with ISS included in our study, it was able to have a beneficial effect. The therapy response was translated into an acceleration of the height's growth, up to normal values according to the biological age. Initiating treatment at smaller chronological ages is recommended especially because, it is well established that, during puberty, gonadal hormones accelerate bone maturation.

\author{
Abbreviations \\ ISS- idiopathic short stature \\ $\mathrm{GH}$ - growth hormone

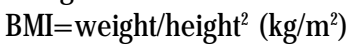 \\ PCR-SSO Polymerase Chain Reaction Sequence Specific \\ Oligonucleotide \\ SD- standard deviation \\ IGF-I- insulin-like growth factor-I \\ DNA-deoxyribonucleic acid \\ MPH-the mean value for the parent's height
}

\section{References}

1.ROSENFELD RG., European J ournal of Endocrinology, Vol 157, suppl 1, 2007, S27-S31

2.FERRY R.J., Quoted from internet @ www.emedicine. com,2004 3.HAN JC., BALAGOPAL P., SWEETEN S., ET AL, Journal Clinical Endocrinology and Metabolism 91:2081-2086, 2006

4.ENE, C.G., ROSU, A., GHEORMAN, V., CALBOREAN, V., TENEA COJAN, T.S., ROGOVEANU, O. C., VLADU, M. I., RADU, L., Incidence of Osteoporosis and the Risk of Fracture in Patients with Rheumatoid Arthritis Undergoing Corticosteroid Treatment, Rev. Chim. (Bucharest), 69, no.7, 2018, p.1851-1854

5.RADU, L., CARSOTE, M., GHEORGHISAN GALATEANU, A.A.. PREDA, S.A., CALBOREAN, V., STANESCU, R., GHEORMAN, V., ALBULESCU, D.M., Blood Parathyrin and Mineral Metabolism Dynamics - A clinical analyze, Rev. Chim.(Bucharest), 69, no. 10, 2018, p. 2754-2758

6.L. RADU, M. CARSOTE, A.M. PREDESCU, T.ST., TENEA-COJAN, B. SOCEA, V.D., BALEANU, M. POPESCU, N, IONOVICI, D.M. ALBULESCU - Biochemical parameters in patients using teriparatide 7.ROSENFELD RG., Horm Res 65(Suppl 1): 15-20, 2006 8.ROSENFELD RG., Growth Horm IGF Res 155: 3-5, 2005 9.SAVAGE MO., CAMACHO-HUBNER C., DAVID A., METHERELL LA., HWA V., ROSENFELD RG., CLARK AJ L., J ournal Clinical Endocrinology and Metabolism 157(suppl 1): S33-S37, 2007

10.PAWLIKOWSK-HADDAL A., Expert Opin Biol Ther, 13(6): 927-932, 2013

11.GIUSTINA A.,VELDHUIS J.D., Endocr. Rev. 19 (1998) 717-797.

12.UDRISTOIU I, MARINESCU I, PIRLOG MC, MILITARU, F, UDRISTOIU, T, MARINESCU, D, MUTICA, $M$, The microvascular alterations in frontal cortex during treatment with antipsychotics: a post-mortem study, Rom J Morphol Embryol, 2016, Vol 57 (2)

13..RICHMOND E., ROGOL AD., Best Practice \& Research Clinical Endocrinology \& Metabolism(2016), doi: 10.1016/j.beem.2016.11.005. 14.ALBULESCU, D.M., PREDA, A.S., CAMEN, A., IONOVICI, N., Rev. Chim. (Bucharest ), 69, no. 7, 2018, p. 1692-1694

15.ROOT AW., DANA K., LIPPE B., Horm Res Paediatr 2011;75:276 - 83. 16.RACHMIEL M., ROTA V., ATENAFU E., DANEMAN D., HAMILTON J., Horm Res 2007;68:236 - 43.

17.BRIDGES N., Archives of Disease in Childhood - Education and Practice 90:7-9, 2005

18.*** National Institute for Clinical Excellance , No 42, 2002 
19.STROBL J S., THOMAS MJ ., Pharmacol Rev 1994;46:1-34.

20.CARROLL PV., CHRIST ER., BENGTSSON BA., CARLSSON L., CHRISTIANSEN JS., CLEMMONS D., ET AL. J Clin Endocri-nol Metab 1998;83:382-95.

21.KIM J., HONG JW., CHUNG YS., KIM SW.,CHO YW.,KIM JH., KIM B] .,LEE EJ ., Yonsei Med J 55(4):1042-1048, 2014

22.VLADU, I.M., RADU, L., GIRGAVU, S.R., TENEA COJAN, T.S., ENE, C.G., CALBOREAN, V.., GHEORMAN, V.,. CLENCIU, D., Alteration of Glucidic Metabolism in Relation with Visceral Adiposity Index Rev. Chim.(Bucharest), 69, no.9, 2018, p.2479-2481

23.TENEA COJ AN, T.S., RADU, L., DAVITOIU,D., VLADU, I.M., BALEANU, V.D,. CLENCIU, D., ENE, C.G., SOCEA,B., The Importance of the Chemical Composition of Synthetic Nets Used in Repair of Parietal Defects, Rev. Chim..(Bucharest), 69 no. 10, 2018, p. 2677-2681 24.MURPHY WR., DAUGHADAY WH., HARTNETT C., J Lab Clin Med $1956 ; 47: 715-722$.

25.OHLSSON C., BENGTSSON BA., ISAKSSON OG., ET AL. Endocr Rev 1998; 19:55-79.

26.VELDHUIS JD., ROEMMICH JN., RICHMOND EJ ., et al., Endocr Rev 2005;26):114-146

27.VERHELST J., MATTSSON AF., LUGER A., THUNANDER M., GÓTH MI., KOLTOWSKA-HÄGGSTROM M., etal., EurJ Endocrinol 2011;165:8819.
28.AHMAD AM., HOPKINS MT., THOMAS I., IBRAHIM H., FRASER WD., VORA JP., Clin Endocrinol (Oxf) 2001;54:709-17.

29. SOCEA, B., RADU, L., CLENCIU, D.,TENEA COJ AN, VT S., BALEANU, V., ENE, C.G., GIRGAVU,S.R., VLADU,I.M., The Utility of Visceral Adiposity Index in Prediction of Metabolic Syndrome and Hypercholesterolemia, Rev. Chim. (Bucharest), 69, no. 11, 2018, p. 3112 - 3114

30VLADU, I.M., RADU, L.,GIRGAVU, S.R., BALEANU, B., CLENCIU, D., ENE, C.G., SOCEA, B., MAZEN, E., CRISTEA, O.M., MOTA, M., TENEA COJAN, T.S., An Easy Way to Detect Cardiovascular Risk, Rev. Chim. (Bucharest), 69, no.11, 2018, p .3329

31. T. S. TENEA COJAN, A. MACOVEI, I PAUN, A I COSTIN, C V GEORGESCU, C. C. GEORGESCU, I. M. VLADU, C. G. ENE, L. RADU, Assessment of hormonal receptor immunoexpression and Her2 status in invasive breast cancer after conservative and radical surgery, Rom J Morphol Embryol 2018, 59(3):763772

32.J ORGENSEN J0., MOLLER L., KRAG M., BILLESTRUP N., CHRISTIANSEN JS., Endocrinol. Metab. Clin. N. Am. 36 (1) (2007) 7587.

33.DOS SANTOS C., ESSIOUX L., TEINTURIER C., ET AL., Nat Genet 2004;36:720-724.

Manuscript received: 27.08 .2018 